This item was submitted to Loughborough's Research Repository by the author.

Items in Figshare are protected by copyright, with all rights reserved, unless otherwise indicated.

\title{
Urban South African adolescents' perceptions of their neighborhood socio- economic environments: the Birth to Twenty plus cohort study
}

PLEASE CITE THE PUBLISHED VERSION

http://dx.doi.org/10.7721/chilyoutenvi.24.3.0173

\section{PUBLISHER}

(c) Children, Youth and Environments

\section{VERSION}

AM (Accepted Manuscript)

\section{PUBLISHER STATEMENT}

This work is made available according to the conditions of the Creative Commons Attribution-NonCommercialNoDerivatives 4.0 International (CC BY-NC-ND 4.0) licence. Full details of this licence are available at: https://creativecommons.org/licenses/by-nc-nd/4.0/

\section{LICENCE}

CC BY-NC-ND 4.0

\section{REPOSITORY RECORD}

Pradeilles, Rebecca, Emily K. Rousham, Shane A. Norris, and Paula L. Griffiths. 2019. "Urban South African Adolescents' Perceptions of Their Neighborhood Socio-economic Environments: The Birth to Twenty Plus Cohort Study". figshare. https://hdl.handle.net/2134/16856. 


\title{
Urban South African Adolescents' Perceptions of Their Neighborhood Socio-Economic Environments: The Birth to Twenty Plus Cohort Study
}

\author{
Rebecca Pradeilles \\ Centre for Global Health and Human Development, School of Sport, Exercise and Health \\ Sciences, Loughborough University \\ MRC/Wits Developmental Pathways for Health Research Unit, University of the \\ Witwatersrand, J ohannesburg, South Africa \\ Emily K. Rousham \\ Centre for Global Health and Human Development, School of Sport, Exercise and Health \\ Sciences, Loughborough University \\ Shane A. Norris \\ MRC/Wits Developmental Pathways for Health Research Unit, University of the \\ Witwatersrand, J ohannesburg, South Africa \\ Paula L. Griffiths \\ Centre for Global Health and Human Development, School of Sport, Exercise and Health \\ Sciences, Loughborough University \\ MRC/Wits Developmental Pathways for Health Research Unit, University of the \\ Witwatersrand, J ohannesburg, South Africa
}

\begin{abstract}
Citation: Pradeilles, Rebecca, Emily K. Rousham, Shane A. Norris, and Paula L. Griffiths (2014). “Urban South African Adolescents' Perceptions of Their

Neighborhood Socio-Economic Environments: The Birth to Twenty Plus Cohort

Study." Children, Youth and Environments 24(3): xx-xx. Retrieved [date] from:

http://www.jstor.org/action/showPublication?journalCode=chilyoutenvi.
\end{abstract}

\begin{abstract}
The Apartheid era led to major differences in the living conditions between population groups in South Africa. Subsequently, reforms have been implemented to reduce poverty and inequalities. This study aims to assess neighborhood and school socio-economic (SE) environments reported by adolescents to determine whether geographic and population group differences in the SE environment exist. Neighborhood SE status was assessed using a novel questionnaire adapted to the urban South African context. Black African and Mixed Ancestry participants lived in more deprived SE environments and reported studying in less favorable school environments compared to Whites. Among Black Africans, those living in Soweto
\end{abstract}


versus metropolitan Johannesburg reported more deprived economic and school environments.

Keywords: South Africa, socio-economic, neighborhood, poverty, inequalities 


\section{Introduction}

South Africa has been exposed to political violence, oppression and Apartheid marginalization for 46 years (Mandela 1994). The Population Registration Act of 1950 required South Africans to be classified into distinct population groups (White, Black African, Indian or Colored (i.e., mixed ancestral origin)). The classification was based on appearance, social acceptance, descent and linguistic ability and determined people's residential area, discriminatory measures against them and in turn their identities and livelihoods (Christopher 1994; Lester, Nel and Binns 2000; Roberts 2001). In 1953, the Reservation of Separate Amenities Act provided a legal basis for the separation of public and private services between Whites and nonWhites. The same year, the Bantu Education Act reinforced inequalities in the education system through the separation of educational facilities between Whites and non-Whites and inferior provision of facilities and resources for Black schools. The Apartheid era led to major differences in the living conditions of these population groups in terms of quality of life, socio-economic status and health (May and Govender 1998; Cameron 2003; Chopra et al. 2009; Richter et al. 2009). In the post-Apartheid era, some of these distinctions are still apparent.

At the end of Apartheid and with a new democratic government in 1994, South Africa began experiencing socio-economic and political changes as well as a rapid urbanization (Jenkins 1997; Seekings 2000). Socio-economic and education reforms targeting the disadvantaged population (mainly Black Africans and Mixed Ancestry) have been implemented in order to alleviate poverty and reduce inequalities. These policies have included fiscal redistribution towards specific areas of need, social policies directed towards the poor, old-age pensions, child support grants, public health care and education (May 2000; Leibbrandt, Wegner and Finn 2011). These programs have aimed to address issues such as lack of schools and school-related facilities and resources, and to improve health service facilities and access to water and sanitation, job creation, economic empowerment, housing conditions, welfare of children, and adult education (May 2000; Cameron 2003).

The existing evidence on the impact of these social and political reforms shows that extreme poverty and inequality increased between 1994 and 2000 (Hoogeveen and Özler 2004; Meth and Dias 2004; Bhorat and Kanbur 2006). The Gini coefficient (a measure of inequality) also increased in South Africa from 57.8 in 2000 to 63.1 in 2009 (World Bank 2014). Perhaps more importantly, within-population group inequality has increased, especially among the Black African population (Bhorat and Kanbur 2006; Leibbrandt, Wegner and Finn 2011). Poverty results are mixed and this is mainly due to the variety of indicators used to measure poverty (headcount poverty measures, income, expenditure, and multidimensional poverty index). Headcount poverty measures have shown that, after increasing between 1995 and 2000 , the proportion of the population living on less than $1 \$ /$ day significantly decreased from 2000 to 2011, despite a plateau from 2006 to 2009 (Hoogeveen and Özler 2004; UNDP 2013). However, these measures do not capture the depth and intensity of poverty for those living below the poverty line. Although access to public health and social services has improved, there has been a rise in unemployment against a background of economic decline since 1994 (Meth and Dias 2004; Bhorat and Kanbur 2006; OECD 2013). 
Poverty and inequality in South Africa has been well researched (Hoogeveen and Özler 2004; Meth and Dias 2004; Bhorat and Kanbur 2006). Socio-economic inequalities can be seen from the individual to the societal level and can be measured objectively and/or subjectively (Posel and Rogan 2013). However, so far, there has been much focus on identifying inequalities at the individual and household levels (Richter et al. 2009; Statistics South Africa 2011). Less is known about inequalities at higher levels of aggregation such as the neighborhood despite the fact that many policies have been implemented at this level.

It is important to understand neighborhood inequalities because detrimental neighborhood environments can have a negative impact, especially on children and adolescents' development, including physical health, well-being, cognitive development, and school achievement as well as emotional and behavioral outcomes (Brooks-Gunn et al. 1993; Brooks-Gunn and Duncan 1997). Negative exposures during childhood and adolescence can, in turn, deeply affect quality of life in adulthood and subsequent generations (Barbarin 2003).

The city of J ohannesburg was known as a divided city during the Apartheid era. The population was segregated into different geographical areas according to population group, national origin, and social class. This led to major differences in the socioeconomic conditions of each area with the poor areas lacking in services and infrastructure (Beall, Crankshaw and Parnell 2000; 2003). The former Black township, Soweto (SOuth WEstern TOwnship), was officially incorporated into the City of Johannesburg in 2000. Understanding how socio-economic inequalities are experienced across population groups as well as between geographical areas within this developing city is therefore important to comprehending the evolution of urban inequalities in South Africa in the post-Apartheid era.

The aim of this study was to assess self-perceived neighborhood deprivation related to the economic, social and school environments of adolescents from the Birth to Twenty Plus cohort-specifically, aged 18 years-living in the area of J ohannesburg and Soweto and to consider population group and geographic differences in these assessments. This study is the first to use a quantitative tool to measure selfperceived deprivation at the neighborhood level amongst adolescents in South Africa. It is also the first cohort that has grown up in the post-Apartheid era. Therefore it is socially very important to understand their perceptions of their environments as they enter adulthood, as well as more broadly to examine perceptions of living in this rapidly changing urban environment with its context of economic and social instability. The findings will identify leverage points for the implementation of adequate policies to target the reduction of neighborhood inequalities for urban South African adolescents.

\section{Methods}

\section{Setting}

Johannesburg-Soweto is situated in the Gauteng province, one of nine provinces in South Africa. Despite having the smallest land area, Gauteng province is the most 
populous province, and Soweto-Johannesburg is the largest urban area in the country. The population of the Gauteng province is composed of 77.4 percent Black Africans, 15.6 percent Whites, 3.5 percent "Colored," 2.9 percent Indian/Asian and 0.7 percent other (Statistics South Africa 2011). Although the city of SowetoJohannesburg has the highest human development index compared to six other cities in South Africa (City of Johannesburg 2005), there are extreme inequalities within the population (Beall, Crankshaw and Parnell 2000), with high rates of poverty, unemployment, violence and crime (de Wet et al. 2008).

This paper focuses on neighborhoods within the area of Johannesburg-Soweto. In this study, neighborhood was defined for each individual as an area that is approximately 2 kilometers from the participant's house in every direction. This radius was chosen as it is the distance from the residence that can be walked in approximately 20 minutes (Sheppard et al. 2010). This definition was reached based on qualitative work conducted with the cohort. As part of this research, adolescents were asked to draw what they perceived to be part of their neighborhoods. Participants expressed that their neighborhood environment included both the geographical area and social networks within that specific area. Although this paper used a seemingly geographical definition of neighborhood, the study also aimed to assess perceptions of participants' place of residence as a community.

\section{Participants}

The data in the present study come from adolescents enrolled in the Birth to Twenty Plus $(B t 20+)$ cohort, who were born and are still residing in urban Johannesburg-Soweto. Bt20+ is a longitudinal cohort study $(n=3273)$ of births occurring April-June 1990 to mothers who were permanent residents of Johannesburg-Soweto. Children have now been followed for 24 years. Bt20+ study is an extension of the Bt20 cohort (as the study has been extended beyond 20 years), which has been described in detail elsewhere (Richter et al. 2007). Bt20 is the largest and longest running cohort study of child health and development in Africa and its longitudinal design brings a unique opportunity to analyze the changing role of socio-economic status (SES) on health in childhood and adolescence. Wealthier White participants are under-represented, as all mothers in the cohort were recruited from public antenatal facilities, which wealthy women did not typically attend (Richter et al. 2007). The attrition rate in this study was estimated to be around 30 percent when participants were aged 16 years old (Richter et al. 2007). Members of the cohort completed an interviewer-administered questionnaire on household and neighborhood SES (Sheppard et al. 2010) when they were aged 16 and repeated at 18 years.

\section{Socioeconomic Status Measures}

\section{Neighborhood SES Measures}

The measure of neighborhood SES represents a challenge in urban areas especially in low- and middle-income countries. To date, very limited tools exist to evaluate neighborhood SES. We assessed neighborhood SES using a novel questionnaire adapted to the urban South African context. This questionnaire was developed for 
use in 2006 and was applied to a sub-sample of the cohort. It was reapplied to the whole cohort in 2008 which is the focus data collection wave of this study. The design of the questionnaire was based on qualitative work conducted with the cohort when they were aged 15 years (Sheppard et al. 2010). Questions related to the economic environment (type of housing, services, facilities, neighborhood problems, etc.); social environment (crime, crime prevention measures, social support, happiness, etc.) and school environment (safety, facilities, etc.) within their neighborhoods. The neighborhood SES indices created in this study have also been used and related to health issues such as systolic blood pressure and anthropometric measures (Griffiths et al. 2012; 2013).

\section{Household SES Measures}

Caregiver (maternal, paternal or other caregiver) education level was assessed as an indicator of household SES. Caregiver education was self-reported by the caregiver when the adolescents were aged less than 18 years old and reported by the adolescents when aged 18 years or more.

\section{Individual Measures}

We collected data on gender, age, place of residence and population group. Population group of the child was identified by the mother as Black African, White, "Colored" or Indian (terms used in the Bt20+ questionnaire) around the time of birth. A decision was made to use the term "Mixed Ancestry" instead of "Colored" for the purposes of this paper.

\section{Statistical Analyses}

\section{Data Management}

Neighborhood SES indices (e.g., neighborhood economic index, neighborhood availability of services index, neighborhood problem index, neighborhood security index, neighborhood social support index, school economic index, school problem index) were created using Principal Component Analysis (PCA) applied to proxy indicators of the neighborhood environment in order to avoid problems of colinearity in the multivariate analyses as there were over 100 questions assessing different aspects of the neighborhood environment in the questionnaire. These were built on indices developed by Griffiths et al. (2012) (see Table 1). There is a debate around the use of indices for measuring SES over individual SES variables (Sheppard et al. 2009). Creating SES indices inevitably loses part of the information collected in the data relating to SES, however when a large number of measures are collected, the use of indices allows statistical models to be more parsimonious.

The neighborhood economic index, availability of services index and problem index reflect the economic aspects of the neighborhoods. The security index and neighborhood social support index reflect the social aspects of the neighborhoods. The school environment aspects are reflected by the school economic index and the school problem index. For each index, the first component score was extracted and the assumption that all eigenvalues should be above 1 was verified. We then created tertiles for each index. The first tertile of each index always represents the most disadvantaged neighborhoods. For example, the third tertile of the 
neighborhood security index reflected higher socio-economic status with more sophisticated and elaborate security measures used in the neighborhood.

We created a categorical variable for caregiver education using the information given (less or equal to primary school, secondary school, higher education).

We created a categorical variable for place of residence denoting adolescents living in Soweto, the rest of Johannesburg metropolitan municipality, or outside of the City of Johannesburg metropolitan municipality. This was done using a geographical mapping system via Google (https://maps.google.co.za/) and a South African postal code system (http://postalcodez.co.za/). For the analyses, we used a dichotomous variable (J ohannesburg vs. Soweto).

\section{Table 1. Description of neighborhood socio-economic and school environment indices created for urban South African adolescents aged 18 years}

Neighborhood economic index: perceptions of neighborhood wealth; outsiders' perceptions of neighborhood wealth; perception of equity of neighborhood living standards; housing quality and condition; availability of yard space; parking space and fencing/walls around properties.

Neighborhood availability of services index: primary and secondary schools; hospitals, health centers; community centers; sports facilities; parks; street lighting; piped water; policing.

Neighborhood problem index: traffic congestion; road safety; sewerage; illegal dumping; pollution, overcrowding; in-migration of non-South Africans; homelessness; repossession of properties; unemployment; prostitution; alcohol/drug abuse; shebeens (bars); and gangs.

Neighborhood social support index: liveliness, spirit and trust levels in the neighborhood; whether neighbors help in a time of need; whether neighbors could be trusted to look after their house; happiness and level of pride in the neighborhood.

Neighborhood security index: whether most households to prevent crime keep weapons; employ security; have dogs; have fences; security doors; barred windows; or security lights.

Neighborhood school economic index: government or private school; safety at school; swimming facilities; library; computer rooms; activities; science labs; sports fields.

Neighborhood school problem index: poor academic standards; lack of resources; lack of discipline; overcrowding; lack of dedicated teachers; teachers who cannot teach well; bullying; bunking off (absenteeism); smoking; alcohol; drugs; weapons; violence; teen pregnancy; rape; and sexual relationships between learners and teachers.

\section{Data Analysis}

2013 (out of 3273) Bt20+ participants completed the neighborhood SES questionnaire at age 18. Those with data on population group, age, gender, place of residence, caregiver education, and neighborhood SES were included in the current analyses (see the flow diagram of exclusions in Figure 1). The breakdown of 
participants by population group was 81.1 percent Black Africans $(n=1633), 6.2$ percent Whites $(n=126), 11.2$ percent Mixed Ancestry $(n=225)$ and 1.5 percent Indians $(n=29)$. Information on caregiver's education was missing for 161 cases due to the fact that contact was required with the caregiver as well as the adolescent to ascertain this information. Indian participants were removed from the univariate and multivariate analyses due to their small sample size $(n=29)$ but were included in the descriptive analysis. Adolescents living outside of the area of metropolitan J ohannesburg and Soweto were also excluded from the univariate and multivariate analyses $(n=191)$ in line with the aim of this study, which was to compare living conditions of adolescents living only in those two areas (Soweto was chosen because of its history as a Black Township area). For the neighborhood security index, 542 observations were either missing or "don't know" answers and were therefore removed in order to run the principal component analysis (PCA). For the neighborhood school environment indices, the sample size was also significantly reduced, as approximately 680 adolescents were not attending school anymore. These cases were removed for analysis purposes for the relevant indices.

\section{Figure 1. Flow diagram to show inclusion of participants from the Bt20+ cohort for each neighborhood SES index}

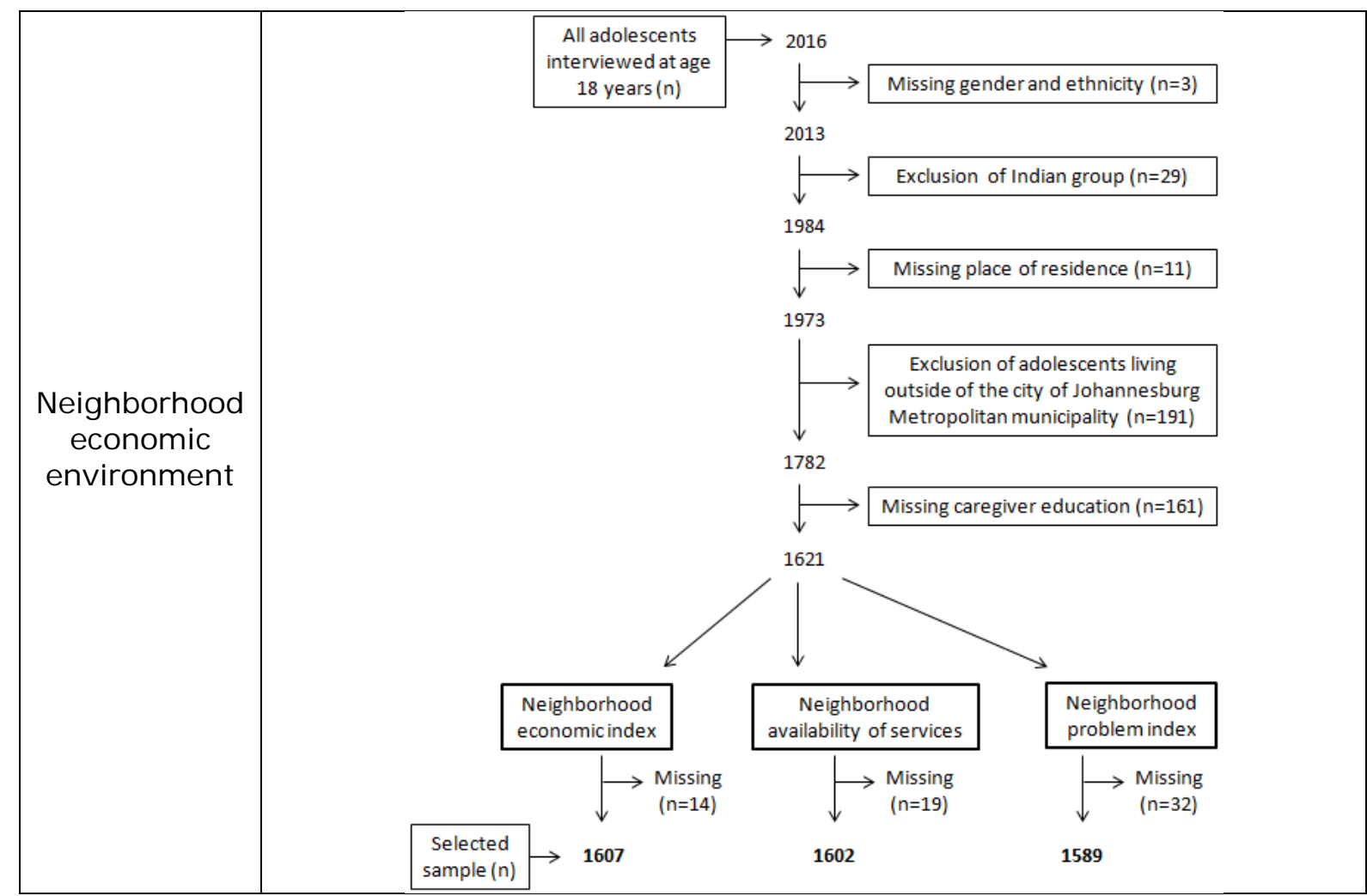




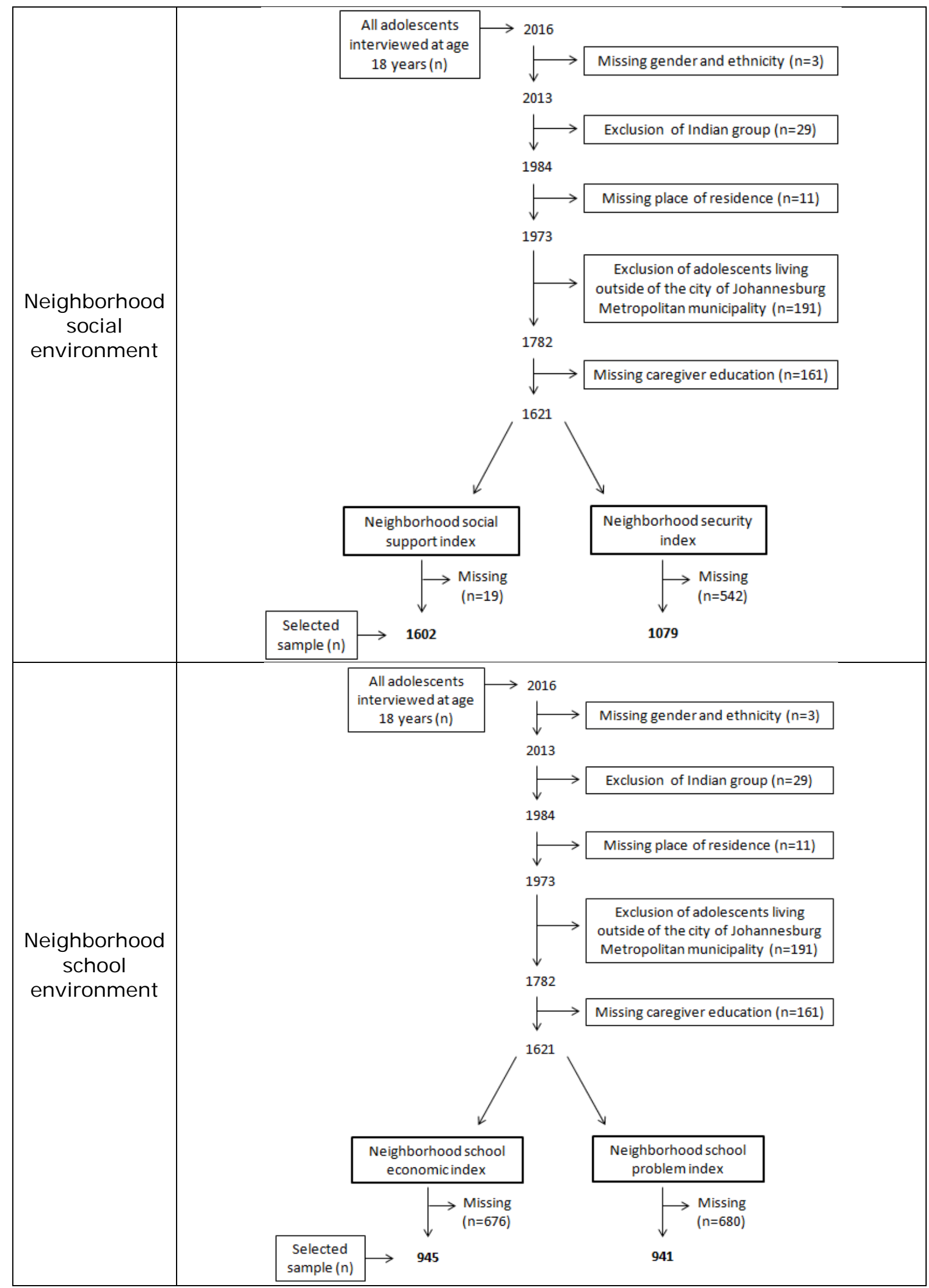


Descriptive statistics were performed on neighborhood SES and caregiver education data, and on individual data. Associations between population group, caregiver education or place of residence and the neighborhood SES tertile measures were examined using ordered logistic regression or generalized ordered logistic models when the parallel regression assumption was violated. Initial unadjusted models were explored followed by multivariate analyses. The explanatory factors modelled were gender, place of residence, caregiver education and population group. The analyses were performed first on the whole sample and then stratified by population group and place of residence. The decision to stratify was based on the hypothesis that socio-economic and school neighborhood perceptions will differ by population group and place of residence and therefore that different patterns will be observed. All analyses were conducted using Stata version 12.

\section{Results}

\section{Descriptive Statistics}

In terms of neighborhood economic environment, Table 2 shows that the majority of Black African and Mixed Ancestry adolescents lived in government housing (37.9 percent and 30.1 percent respectively) and improved government housing (34.4 percent and 29.1 percent respectively) while White adolescents lived predominantly in bond housing (privately owned), flats or townhouses ( 95.0 percent). Half of the Indian adolescents lived in bond housing, flats or townhouses ( 51.7 percent).

Around half of the Black African, Mixed Ancestry and Indian sample reported living in good condition housing (49.1 percent, 47.3 percent and 51.7 percent, respectively) as opposed to 77.0 percent in the White sample. Fewer White adolescents perceived themselves as poor (4.8 percent) compared with 13.6 percent and 16.8 percent of Black African and Mixed Ancestry adolescents, respectively.

Significantly more Black African adolescents than Whites reported that their neighborhoods had low availability of public services such as primary and secondary schools, health facilities such as hospitals and primary health clinics, and community and recreational facilities (see Table 2). The same tendency was seen for Mixed Ancestry adolescents in comparison to Whites. Black African, Mixed Ancestry and Indian adolescents reported a lower availability of sports facilities, park and police officers patrolling neighborhood in comparison to Whites. Mixed Ancestry, Black African and Indian groups experienced more problems in their neighborhood compared to the White group. The main problems reported were unemployment, alcohol abuse, shebeens (bars), drugs, gangsterism and illegal dumping. Although similar patterns were observed between Black African and Mixed Ancestry adolescents, the prevalence of problems related to drugs and gangsterism was higher in the Mixed Ancestry group: 79.6 percent and 74.2 percent of Mixed Ancestry adolescents reported problems with drugs and gangsterim, respectively, compared to 60.1 percent and 59.9 percent in the Black African group. The prevalence of problems related to prostitution was higher in the Mixed Ancestry group (19.2 percent) compared to the White group (7.9 percent). 
In terms of neighborhood social environment, Black African and Mixed Ancestry groups were more likely to report feeling unsafe in their neighborhood (13.6 percent and 13.9 percent, respectively) as opposed to 5.6 percent in the White group (Table 2). A high amount of neighborhood crime was reported by 31.7 percent of the Mixed Ancestry sample and 22.7 percent of the Black Africans, which was significantly different from the White sample (7.9 percent). Black African, Mixed Ancestry and Indian adolescents reported spending time with their friends more often than White adolescents. Indeed, 36.2 percent of Black African adolescents, 48.7 percent of Mixed Ancestry adolescents and 51.8 percent of Indian adolescents reported spending time with their friends on a daily basis as opposed to 13.5 percent in the White group. The atmosphere in the neighborhood and the community spirit was reported predominantly as lively and strong in the Black African, Mixed Ancestry and Indian groups. For instance, the community spirit was reported as strong by 38.4 percent of Black African adolescents and 35.3 percent of Mixed Ancestry adolescents as opposed to 9.5 percent in the White group. The prevalence of security measures used to ensure safety was high across the different population groups although noticeably higher in the White group. Among the Black African and Mixed Ancestry groups, the security measures mainly adopted were dogs, high walls and barred windows.

The proportion of adolescents who reported feeling unsafe or only moderately safe at school was substantial at 19.3 percent (Table 2). The proportion of adolescents feeling unsafe was higher in the Black African (6.5 percent) and Mixed Ancestry (2.6 percent) groups compared to Whites ( 1.0 percent). Black African and Mixed Ancestry adolescents reported experiencing more problems at school such as teenage pregnancy, violence, bullying, weapons, poor educational environment (lack of discipline, teachers who cannot teach well, lack of dedicated teachers, poor academic standards, teachers under the influence of alcohol during teaching hours) in comparison to Whites. 
Table 2. Descriptive statistics (overall and by population groups) related to the neighborhood socio-economic and school environments reported by urban South African adolescents aged 18 years

\begin{tabular}{|c|c|c|c|c|c|c|c|c|c|c|}
\hline & \multicolumn{2}{|c|}{ Total } & \multicolumn{2}{|c|}{ Black Africans } & \multicolumn{2}{|c|}{ Mixed Ancestry } & \multicolumn{2}{|c|}{ Indians } & \multicolumn{2}{|c|}{ Whites } \\
\hline & $\mathbf{n}$ & $\%$ & $\mathbf{n}$ & $\%$ & n & $\%$ & $\mathbf{n}$ & $\%$ & n & $\%$ \\
\hline Type of housing & 1980 & & 1609 & $* * *$ & 223 & $* * *$ & 29 & $* * *$ & 119 & \\
\hline Shacks & 89 & 4.5 & 77 & 4.8 & 11 & 4.9 & 1 & 3.5 & 0 & 0 \\
\hline Government housing/flats & 685 & 34.6 & 610 & 37.9 & 67 & 30.1 & 5 & 17.2 & 3 & 2.5 \\
\hline $\begin{array}{l}\text { Improved government } \\
\text { housing/flats }\end{array}$ & 630 & 31.8 & 554 & 34.4 & 65 & 29.1 & 8 & 27.6 & 3 & 2.5 \\
\hline $\begin{array}{l}\text { Bond housing/ flats/ } \\
\text { townhouses }\end{array}$ & 576 & 29.1 & 368 & 22.9 & 80 & 35.9 & 15 & 51.7 & 113 & 95.0 \\
\hline Housing condition & 2007 & & 1626 & $* * *$ & 226 & $* * *$ & 29 & $* *$ & 126 & \\
\hline Bad & 162 & 8.0 & 132 & 8.1 & 27 & 12.0 & 2 & 6.9 & 1 & 0.8 \\
\hline Average & 828 & 41.3 & 696 & 42.8 & 92 & 40.7 & 12 & 41.4 & 28 & 22.2 \\
\hline Good & 1017 & 50.7 & 798 & 49.1 & 107 & 47.3 & 15 & 51.7 & 97 & 77.0 \\
\hline Perceptions of wealth & 2008 & & 1627 & $* * *$ & 226 & $* * *$ & 29 & $* *$ & 126 & \\
\hline Poor & 267 & 13.3 & 221 & 13.6 & 38 & 16.8 & 2 & 6.9 & 6 & 4.8 \\
\hline Average & 1401 & 69.8 & 1169 & 71.8 & 147 & 65.0 & 23 & 79.3 & 62 & 49.2 \\
\hline Wealthy & 340 & 16.9 & 237 & 14.6 & 41 & 18.2 & 4 & 13.8 & 58 & 46 \\
\hline \multicolumn{11}{|c|}{ Lack of availability of services } \\
\hline $\begin{array}{l}\text { Police officers patrolling } \\
\text { neighborhood }\end{array}$ & 1528 & 76.3 & 1257 & $77.5^{* * *}$ & 173 & $76.5^{* *}$ & 24 & $82.8^{*}$ & 74 & 58.7 \\
\hline Hospital & 1386 & 69.2 & 1179 & $72.7^{* * *}$ & 153 & $67.7^{* * *}$ & 12 & 41.4 & 42 & 33.3 \\
\hline $\begin{array}{l}\text { Community/recreational } \\
\text { center }\end{array}$ & 1253 & 62.5 & 1054 & $65.0^{* * *}$ & 129 & $57.1^{*}$ & 15 & 51.7 & 55 & 43.7 \\
\hline $\begin{array}{l}\text { Sports field, pool or tennis } \\
\text { courts }\end{array}$ & 1237 & 61.8 & 1050 & $64.7^{* * *}$ & 129 & $57.1^{* * *}$ & 17 & $58.6^{*}$ & 41 & 32.5 \\
\hline Primary health clinic & 1202 & 60 & 1002 & $61.7^{* * *}$ & 134 & $59.6 * *$ & 15 & 51.7 & 51 & 40.5 \\
\hline Park & 1047 & 52.3 & 896 & $55.3^{* * *}$ & 113 & $50.0 * * *$ & 13 & $44.8^{* *}$ & 25 & 19.8 \\
\hline Working street lighting & 1009 & 50.4 & 838 & $51.6^{* * *}$ & 126 & $55.7^{* * *}$ & 16 & $55.2^{* *}$ & 29 & 23.2 \\
\hline Piped water supply & 769 & 38.4 & 655 & $40.4^{* * *}$ & 90 & $39.8^{* * *}$ & 11 & $37.9^{* *}$ & 13 & 10.3 \\
\hline Secondary school & 754 & 37.6 & 654 & $40.3^{* * *}$ & 68 & $30.1^{*}$ & 7 & 24.1 & 25 & 19.9 \\
\hline Primary school & 567 & 28.4 & 494 & $30.5^{* * *}$ & 51 & $22.7^{*}$ & 7 & 24.1 & 15 & 11.9 \\
\hline \multicolumn{11}{|l|}{ Problems in neighborhood } \\
\hline Unemployment & 1624 & 81 & 1370 & $84.4^{* * *}$ & 187 & $83.1^{* * *}$ & 19 & $65.5^{* *}$ & 48 & 38.1 \\
\hline Alcohol abuse & 1496 & 74.7 & 1254 & $77.3^{* * *}$ & 170 & $75.6^{* * *}$ & 20 & $69.0^{* *}$ & 52 & 41.3 \\
\hline Shebeens (bars) & 1477 & 73.7 & 1256 & $77.4^{* * *}$ & 179 & $79.6^{* * *}$ & 15 & $51.7^{* *}$ & 27 & 21.4 \\
\hline Drugs & 1216 & 60.8 & 975 & $60.1^{* * *}$ & 179 & $79.6^{* * *}$ & 21 & $72.4^{* * *}$ & 41 & 32.5 \\
\hline Gangsters & 1178 & 58.8 & 972 & $59.9 * * *$ & 167 & $74.2 * * *$ & 16 & $55.2^{* * *}$ & 23 & 18.2 \\
\hline Illegal dumping & 1142 & 56.9 & 946 & $58.2^{* * *}$ & 146 & $64.6^{* * *}$ & 16 & $55.2^{* *}$ & 34 & 27.0 \\
\hline Delinquency & 1098 & 54.8 & 913 & $56.3^{* * *}$ & 141 & $62.7^{* * *}$ & 11 & 37.9 & 33 & 26.2 \\
\hline Overcrowding & 771 & 38.5 & 673 & $41.5^{* * *}$ & 82 & $36.3^{* * *}$ & 5 & 17.2 & 11 & 8.7 \\
\hline Sewerage & 741 & 36.9 & 637 & $39.2^{* * *}$ & 87 & $38.5^{* * *}$ & 6 & 20.7 & 11 & 8.7 \\
\hline Road rage & 614 & 30.6 & 479 & 29.5 & 86 & 38.0 & 11 & 37.9 & 38 & 30.2 \\
\hline Minority attacks & 547 & 27.3 & 457 & $28.2^{* * *}$ & 81 & $35.8^{* * *}$ & 4 & 13.8 & 5 & 4.0 \\
\hline Homelessness & 517 & 25.8 & 382 & $23.5^{*}$ & 83 & 37.0 & 12 & 41.4 & 40 & 31.7 \\
\hline Prostitution & 239 & 11.9 & 180 & 11.1 & 43 & $19.2^{* *}$ & 6 & 20.7 & 10 & 7.9 \\
\hline
\end{tabular}

Significance values are for trends from unadjusted logistic or ordered logistic regression using whites as reference category; ${ }^{*} p<0.05,{ }^{* *} p<0.01, * * * p<0.001$ 
Table 2, cont. Descriptive statistics (overall and by population groups) related to the neighborhood socio-economic and school environment reported by urban South African adolescents aged 18 years

\begin{tabular}{|c|c|c|c|c|c|c|c|c|c|c|}
\hline & \multicolumn{2}{|c|}{ Total } & \multicolumn{2}{|c|}{ Black Africans } & \multicolumn{2}{|c|}{ Mixed Ancestry } & \multicolumn{2}{|c|}{ Indians } & \multicolumn{2}{|c|}{ Whites } \\
\hline & $\mathbf{n}$ & $\%$ & $\mathbf{n}$ & $\%$ & $\mathbf{n}$ & $\%$ & $\mathbf{n}$ & $\%$ & $\mathbf{n}$ & $\%$ \\
\hline Feeling of safety & 2001 & & 1623 & & 223 & & 29 & & 126 & \\
\hline Unsafe & 259 & 13.0 & 220 & 13.6 & 31 & 13.9 & 1 & 3.5 & 7 & 5.6 \\
\hline Moderate & 619 & 30.9 & 492 & 30.3 & 76 & 34.1 & 7 & 24.1 & 44 & 34.9 \\
\hline Safe & 1123 & 56.1 & 911 & 56.1 & 116 & 52 & 21 & 72.4 & 75 & 59.5 \\
\hline Level of crime & 2002 & & 1623 & * & 224 & $* * *$ & 29 & & 126 & \\
\hline A lot & 454 & 22.7 & 368 & 22.7 & 71 & 31.7 & 5 & 17.2 & 10 & 7.9 \\
\hline Some & 587 & 29.3 & 477 & 29.4 & 57 & 25.5 & 9 & 31.0 & 44 & 34.9 \\
\hline Average & 467 & 23.3 & 376 & 23.2 & 48 & 21.4 & 5 & 17.2 & 38 & 30.2 \\
\hline Not much & 404 & 20.2 & 328 & 20.2 & 38 & 17.0 & 9 & 31.0 & 29 & 23.0 \\
\hline None & 90 & 4.5 & 74 & 4.5 & 10 & 4.4 & 1 & 3.6 & 5 & 4.0 \\
\hline $\begin{array}{l}\text { Time spent with friends in } \\
\text { the neighborhood }\end{array}$ & 2000 & & 1621 & $* * *$ & 224 & $* * *$ & 29 & $* * *$ & 126 & \\
\hline Never & 312 & 15.6 & 249 & 15.4 & 33 & 14.7 & 3 & 10.3 & 27 & 21.4 \\
\hline Less than once a week & 232 & 11.6 & 188 & 11.6 & 16 & 7.1 & 1 & 3.5 & 27 & 21.4 \\
\hline Once a week & 276 & 13.8 & 226 & 13.9 & 32 & 14.3 & 3 & 10.3 & 15 & 12.0 \\
\hline 2-6 times a week & 452 & 22.6 & 371 & 22.9 & 34 & 15.2 & 7 & 24.1 & 40 & 31.7 \\
\hline Daily & 728 & 36.4 & 587 & 36.2 & 109 & 48.7 & 15 & 51.8 & 17 & 13.5 \\
\hline $\begin{array}{l}\text { Liveliness in the } \\
\text { neighborhood }\end{array}$ & 2000 & & 1621 & $* * *$ & 224 & $* *$ & 29 & & 126 & \\
\hline Not very lively & 362 & 18.2 & 279 & 17.2 & 40 & 17.9 & 8 & 27.6 & 35 & 27.8 \\
\hline Average & 805 & 40.2 & 657 & 40.5 & 85 & 37.9 & 6 & 20.7 & 57 & 45.2 \\
\hline Lively & 833 & 41.6 & 685 & 42.3 & 99 & 44.2 & 15 & 51.7 & 34 & 27.0 \\
\hline Community spirit & 1997 & & 1621 & $* * *$ & 221 & $* * *$ & 29 & $*$ & 126 & \\
\hline Weak & 546 & 27.3 & 413 & 25.5 & 67 & 30.3 & 7 & 24.1 & 59 & 46.8 \\
\hline Average & 731 & 36.6 & 585 & 36.1 & 76 & 34.4 & 15 & 51.8 & 55 & 43.6 \\
\hline Strong & 720 & 36.1 & 623 & 38.4 & 78 & 35.3 & 7 & 24.1 & 12 & 9.6 \\
\hline \multicolumn{11}{|l|}{ Security measures } \\
\hline High walls/fences/gates & 1631 & 81.8 & 1314 & $81.3^{* * *}$ & 171 & $77.4^{* * *}$ & 24 & $82.8^{* *}$ & 122 & 96.8 \\
\hline Barred windows & 1594 & 81.0 & 1289 & $80.8^{* *}$ & 163 & $73.4^{* * *}$ & 20 & $71.4^{* * *}$ & 122 & 99.2 \\
\hline Dogs & 1561 & 79.0 & 1244 & $77.6^{* *}$ & 179 & $81.7^{*}$ & 24 & 85.7 & 114 & 90.5 \\
\hline Weapons & 888 & 61.4 & 709 & 60.1 & 116 & 67.8 & 16 & 64 & 47 & 66.2 \\
\hline Security doors & 1108 & 58.4 & 861 & $56.2^{* * *}$ & 111 & $50.9 * * *$ & 18 & $64.3^{* * *}$ & 118 & 99.2 \\
\hline Security lights & 872 & 46.1 & 654 & $43.0^{* * *}$ & 89 & $40.8^{* * *}$ & 18 & $64.3^{* *}$ & 111 & 90.2 \\
\hline Electric fences & 774 & 39.2 & 552 & $34.6^{* * *}$ & 87 & $38.8^{* * *}$ & 18 & $62.1^{* * *}$ & 117 & 93.6 \\
\hline Alarms/panic buttons & 732 & 39.2 & 482 & $32.1^{* * *}$ & 110 & $51.2 * * *$ & 21 & $75.0 * *$ & 119 & 96 \\
\hline Security guards & 640 & 33.0 & 469 & $29.8^{* * *}$ & 59 & $27.2^{* * *}$ & 13 & $44.8 * * *$ & 99 & 81.1 \\
\hline
\end{tabular}

Significance values are for trends from unadjusted logistic or ordered logistic regression using whites as reference category; ${ }^{*} \mathrm{p}<0.05,{ }^{* *} \mathrm{p}<0.01,{ }^{* * *} \mathrm{p}<0.001$ 
Table 2, cont. Descriptive statistics (overall and by population groups) related to the neighborhood socio-economic and school environment reported by urban South African adolescents aged 18 years

\begin{tabular}{|c|c|c|c|c|c|c|c|c|c|c|}
\hline & \multicolumn{2}{|c|}{$\begin{array}{l}\text { Total } \\
\end{array}$} & \multicolumn{2}{|c|}{ Black Africans } & \multicolumn{2}{|c|}{ Mixed Ancestry } & \multicolumn{2}{|c|}{ Indians } & \multicolumn{2}{|c|}{ Whites } \\
\hline & $\mathbf{n}$ & $\%$ & $\mathbf{n}$ & $\%$ & $\mathbf{n}$ & $\%$ & $\mathbf{n}$ & $\%$ & $\mathbf{n}$ & $\%$ \\
\hline Safety at school & 1243 & & 1056 & & 76 & & 16 & & 95 & \\
\hline Unsafe & 72 & 5.8 & 69 & 6.5 & 2 & 2.6 & - & _- & 1 & 1.0 \\
\hline Moderate & 166 & 13.4 & 140 & 13.3 & 11 & 14.5 & 2 & 12.5 & 13 & 13.7 \\
\hline Safe & 1005 & 80.8 & 847 & 80.2 & 63 & 82.9 & 14 & 87.5 & 81 & 85.3 \\
\hline \multicolumn{11}{|l|}{ Problems at school } \\
\hline Smoking & 1045 & 84.5 & 906 & $86.1^{* *}$ & 57 & 77 & 11 & 73.3 & 71 & 74.7 \\
\hline Bunking off (absenteeism) & 806 & 65.2 & 688 & 65.4 & 47 & 63.5 & 9 & 60.0 & 62 & 65.3 \\
\hline Teenage pregnancy & 792 & 64.1 & 718 & $68.3^{* * *}$ & 48 & $64.9 * * *$ & 5 & 33.3 & 21 & 22.1 \\
\hline $\begin{array}{l}\text { Learners under the } \\
\text { influence of alcohol during } \\
\text { teaching hours }\end{array}$ & 558 & 45.1 & 491 & $46.7^{* *}$ & 29 & 39.2 & 7 & 46.7 & 31 & 32.6 \\
\hline Overcrowding & 496 & 40.2 & 428 & 40.7 & 29 & 39.2 & 7 & 46.7 & 32 & 33.7 \\
\hline Lack of discipline & 471 & 38.1 & 414 & $39.3^{* * *}$ & 34 & $46.6^{* * *}$ & 5 & 33.3 & 18 & 18.9 \\
\hline Violence & 449 & 36.4 & 398 & $37.9^{* * *}$ & 36 & $48.7^{* * *}$ & 6 & $40 * *$ & 9 & 9.5 \\
\hline Bullying & 420 & 34.0 & 377 & $35.9^{* * *}$ & 33 & $44.6^{* * *}$ & 2 & 13.3 & 8 & 8.4 \\
\hline $\begin{array}{l}\text { Teachers who cannot teach } \\
\text { well }\end{array}$ & 402 & 32.5 & 340 & $32.3^{* *}$ & 28 & $37.8^{* *}$ & 7 & 46.7 & 27 & 28.4 \\
\hline Drugs & 382 & 31.1 & 328 & 31.4 & 24 & 32.4 & 5 & 33.3 & 25 & 26.6 \\
\hline Weapons & 332 & 27.0 & 291 & $27.9^{* * *}$ & 29 & $39.2^{* * *}$ & 5 & $33.3^{* *}$ & 7 & 7.4 \\
\hline Lack of dedicated teachers & 304 & 24.6 & 264 & $25.1^{* *}$ & 25 & $33.8^{* *}$ & 3 & 20.0 & 12 & 12.6 \\
\hline Poor academic standards & 281 & 22.7 & 244 & $23.2^{* *}$ & 24 & $32.4^{* * *}$ & 4 & 26.7 & 9 & 9.5 \\
\hline $\begin{array}{l}\text { Sexual relationships } \\
\text { between learners and } \\
\text { teachers }\end{array}$ & 260 & 21.5 & 245 & $23.9^{* * *}$ & 9 & 12.5 & 2 & 14.3 & 4 & 4.2 \\
\hline $\begin{array}{l}\text { Teachers under the } \\
\text { influence of alcohol during } \\
\text { teaching hours }\end{array}$ & 166 & 13.5 & 149 & $14.2^{* *}$ & 13 & $17.6 * *$ & 2 & 13.3 & 2 & 2.1 \\
\hline Rape & 55 & 4.5 & 46 & 4.4 & 4 & 5.5 & 2 & 13.3 & 3 & 3.2 \\
\hline
\end{tabular}

Significance values are for trends from unadjusted logistic or ordered logistic regression using whites as reference category; ${ }^{*} p<0.05, * * p<0.01, * * * p<0.001$

\section{Multivariate Analyses}

\section{Self-Perceived Neighborhood Economic Environment}

\section{Total Sample}

Highly significant associations were found between population group and the three neighborhood economic indices (neighborhood economic index $(p<0.0001$ ), neighborhood availability of service index $(p<0.0001)$, and neighborhood problem 
index $(p<0.0001)$ ) in the adjusted models (Table 3). Being Black African in comparison to White reduced the odds of having a higher economic index by 91 percent $(\mathrm{OR}=0.09[0.03-0.24])$. Being Mixed Ancestry also reduced the odds of having a higher economic index $(O R=0.08$ [0.03-0.22]. Being Black African also reduced the odds of having a high neighborhood availability of services by 72 percent $(\mathrm{OR}=0.28[0.17-0.47])$. The same association was seen in Mixed Ancestry adolescents $(\mathrm{OR}=0.30$ [0.17-0.51]). Finally, being Black African or Mixed Ancestry versus White reduced the odds of low neighborhood problems $(O R=0.25$ [0.15$0.42]$ and $(\mathrm{OR}=0.17[0.09-0.29])$, respectively).

Significant associations were also found between the caregiver's education and the three neighborhood economic indices ( $p \leq 0.0001)$. Living with a non-educated caregiver or a caregiver who achieved only primary school in comparison to a higher educated caregiver reduced the odds of 1 ) having a higher neighborhood economic index by 79 percent $(O R=0.21[0.13-0.34]) ; 2)$ having a high availability of services by 56 percent $(\mathrm{OR}=0.44[0.30-0.63])$; and 3$)$ experiencing low neighborhood problems by 48 percent $(O R=0.52[0.36-0.75]$. The same tendency was found when comparing a caregiver who achieved only secondary school in comparison to a higher-educated caregiver.

Place of residence was associated with the neighborhood economic index $(p=0.035)$. Living in metropolitan Johannesburg in comparison to Soweto increased the odds of having a higher neighborhood economic index ( $O R=1.54$ [1.03-2.29]).

Males and females perceived the neighborhood economic environment differently. Being female vs. male reduced the odds of having a higher neighborhood economic index by 18 percent $(O R=0.82$ [0.68-0.99]) (data not shown).

\section{Black African Adolescent Subsample}

The same patterns were observed in the subsample of only Black African adolescents. Strong associations were found between the caregiver's education and the three neighborhood economic indices (Table 3). Living in metropolitan Johannesburg rather than Soweto increased the odds of having a higher economic index $(\mathrm{OR}=1.74$ [1.02-2.95]). After adjustment for caregiver education, there was no significant difference in neighborhood availability of services and problems between Black Africans living in metropolitan Johannesburg and those living in Soweto.

Perceptions of the neighborhood problem environment differed by gender. Black African females were more likely to report lower problems in comparison to Black African males $(\mathrm{OR}=1.24[1.02-1.52])$. 


\section{Table 3. Self-perceived neighborhood economic environment for urban South African adolescents aged 18 years}

\begin{tabular}{|c|c|c|c|c|c|c|c|c|c|c|c|c|c|c|c|c|c|c|}
\hline & \multicolumn{6}{|c|}{$\begin{array}{l}\text { Neighborhood economic index } \\
\text { (tertiles) }\end{array}$} & \multicolumn{6}{|c|}{$\begin{array}{c}\text { Neighborhood availability of services } \\
\text { index (tertiles) }\end{array}$} & \multicolumn{6}{|c|}{$\begin{array}{c}\text { Neighborhood problem index } \\
\text { (tertiles) }\end{array}$} \\
\hline & & \multirow{2}{*}{$\%$} & \multicolumn{2}{|c|}{ Unadjusted } & \multicolumn{2}{|c|}{ Adjusted } & & & \multicolumn{2}{|c|}{ Unadjusted } & \multicolumn{2}{|c|}{ Adjusted } & & \multirow{2}{*}{$\%$} & \multicolumn{2}{|c|}{ Unadjusted } & \multicolumn{2}{|c|}{ Adjusted } \\
\hline & & & OR & $\mathrm{Cl}$ & OR & $\mathrm{Cl}$ & & & OR & $\mathrm{Cl}$ & OR & $\mathrm{Cl}$ & & & OR & $\mathrm{Cl}$ & OR & $\mathrm{Cl}$ \\
\hline \multicolumn{19}{|c|}{ Total sample* } \\
\hline \multicolumn{3}{|c|}{ Population group } & \multicolumn{2}{|c|}{$p<0.0001$} & \multicolumn{2}{|c|}{$p<0.0001$} & \multicolumn{4}{|c|}{$p<0.0001$} & \multicolumn{2}{|c|}{$p<0.0001$} & \multicolumn{4}{|c|}{$p<0.0001$} & \multicolumn{2}{|c|}{$p<0.0001$} \\
\hline Jhite & 14 & 4 & 1 & - & 1 & - & 13 & 6.4 & 1 & - & 1 & - & 114 & 6.5 & 1 & - & 1 & - \\
\hline lack & 1446 & 81.4 & 0.10 & $\begin{array}{c}0.06- \\
0.15 \\
\end{array}$ & 0.09 & $\begin{array}{c}0.03- \\
0.24 \\
\end{array}$ & 1441 & 81.4 & 0.18 & $\begin{array}{l}0.12- \\
0.27\end{array}$ & 0.28 & $\begin{array}{l}0.17- \\
0.47\end{array}$ & 1428 & 81.4 & 0.21 & $\begin{array}{l}0.14- \\
0.31 \\
\end{array}$ & 0.25 & $\begin{array}{l}0.15 \\
0.42 \\
\end{array}$ \\
\hline & 17 & 12.2 & 0.09 & $\begin{array}{l}0.05- \\
0.15\end{array}$ & 0.08 & $\begin{array}{l}0.03- \\
0.22 \\
\end{array}$ & 217 & 12.2 & 0.23 & $\begin{array}{l}0.14- \\
0.36 \\
\end{array}$ & 0.30 & $\begin{array}{c}0.17- \\
0.51 \\
\end{array}$ & 213 & 12.1 & .14 & & .17 & $\begin{array}{l}0.09 \\
0.29 \\
\end{array}$ \\
\hline \multicolumn{3}{|c|}{ Caregiver education } & \multicolumn{2}{|c|}{$p<0.0001$} & \multicolumn{2}{|c|}{$p<0.0001$} & \multicolumn{4}{|c|}{$p<0.0001$} & \multicolumn{2}{|c|}{$p=0.0001$} & & & $\mathrm{p}<0$. & 0001 & $p<0$. & .0001 \\
\hline & 11 & 13.1 & 1 & - & 1 & - & 212 & 13.2 & 1 & - & 1 & - & 207 & 13.0 & 1 & - & 1 & - \\
\hline & 157 & 71.9 & 21 & 0.28 & 0.28 & $\begin{array}{c}0.20- \\
0.39 \\
\end{array}$ & 1153 & 71.9 & 0.41 & & 0.57 & & 1143 & 71.8 & 0.34 & & 0.46 & $\begin{array}{l}0.34 \\
0.63 \\
\end{array}$ \\
\hline & 41 & 15.0 & 15 & $\begin{array}{l}0.10- \\
0.23\end{array}$ & 0.21 & $\begin{array}{c}0.13- \\
0.34\end{array}$ & 239 & 14.9 & 0.30 & $\begin{array}{c}0.21- \\
0.43\end{array}$ & 0.44 & $\begin{array}{c}0.30- \\
0.63\end{array}$ & 241 & 15.2 & 0.37 & $\begin{array}{c}0.26- \\
0.53\end{array}$ & 0.52 & $\begin{array}{l}0.36 \\
0.75 \\
\end{array}$ \\
\hline Plac & nce & & $p<0$. & .0001 & $\mathrm{p}=0$. & .035 & & & $p<0$ & 0001 & $p=0$ & .081 & & & $\mathrm{p}<0$. & 0001 & & 0.63 \\
\hline Sow & 379 & 78.0 & 1 & - & 1 & - & 375 & 78.1 & 1 & - & 1 & - & 1364 & 78.1 & 1 & - & 1 & - \\
\hline & 388 & 22.0 & 3.51 & $\begin{array}{l}2.36- \\
5.23\end{array}$ & 1.54 & $\begin{array}{l}1.03- \\
2.29\end{array}$ & 386 & 21.9 & 1.97 & $\begin{array}{l}1.59- \\
2.44\end{array}$ & 1.26 & $\begin{array}{c}0.97- \\
1.64\end{array}$ & 382 & 21.9 & 1.85 & $\begin{array}{l}1.42- \\
2.40\end{array}$ & 1.07 & $\begin{array}{r}0.82 \\
1.40\end{array}$ \\
\hline Sample o & ck & do & ents* & & & & & & & & & & & & & & & \\
\hline Care & ti & & $p<0$. & .0001 & $p<0$. & .0001 & & & $p<0$. & .0001 & $p=0$. & .0001 & & & $p<0$. & 001 & $p=0$. & .0001 \\
\hline 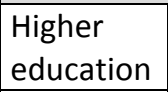 & 33 & 10.1 & 1 & - & 1 & - & 133 & 10.1 & 1 & - & 1 & - & 128 & 9.8 & 1 & - & 1 & - \\
\hline $\begin{array}{l}\text { Secondary } \\
\text { school }\end{array}$ & J & 73.6 & 0.29 & $\begin{array}{c}0.20- \\
0.41\end{array}$ & 0 & $\begin{array}{l}0.21- \\
0.45\end{array}$ & 965 & 73.6 & 0.50 & $\begin{array}{l}0.35- \\
0.70\end{array}$ & 0.5 & $\begin{array}{l}0.37- \\
0.74\end{array}$ & 959 & 73.7 & 0.44 & $\begin{array}{l}0.31- \\
0.63\end{array}$ & 0.46 & $\begin{array}{l}0.32 \\
0.65 \\
\end{array}$ \\
\hline $\begin{array}{l}\text { Primary } \\
\text { school } \\
\end{array}$ & 215 & 16.3 & 0.21 & $\begin{array}{l}0.12- \\
0.35\end{array}$ & 0.22 & $\begin{array}{c}0.13- \\
0.38 \\
\end{array}$ & 214 & 16.3 & 0.39 & $\begin{array}{l}0.26- \\
0.59 \\
\end{array}$ & 0.41 & $\begin{array}{l}0.27- \\
0.62 \\
\end{array}$ & 215 & 16.5 & 0.51 & $\begin{array}{l}0.34- \\
0.78 \\
\end{array}$ & 0.53 & $\begin{array}{l}0.35 \\
0.80 \\
\end{array}$ \\
\hline Place & sidence & & $p=0$ & .038 & $\mathrm{p}=0$. & .042 & & & $p=0$ & .041 & $p=0$ & 0.071 & & & $p=0$ & .123 & $p=0$ & 0.530 \\
\hline Soweto & 243 & 86.6 & - & - & 1 & - & 240 & 86.7 & 1 & - & 1 & - & 1231 & 86.8 & 1 & - & 1 & - \\
\hline $\begin{array}{l}\text { Johannes- } \\
\text { burg }\end{array}$ & 193 & 13.4 & J./. & $\begin{array}{l}1.03- \\
2.97\end{array}$ & 1.74 & $\begin{array}{l}1.02- \\
2.95\end{array}$ & 1 & 13.3 & 1.34 & $\begin{array}{l}1.01- \\
1.77\end{array}$ & 1.32 & $\begin{array}{c}0.98- \\
1.78\end{array}$ & 188 & 13.2 & 1.35 & $\begin{array}{l}0.92- \\
1.98\end{array}$ & 1.10 & $\begin{array}{l}0.81 \\
1.51\end{array}$ \\
\hline
\end{tabular}

*Adjusted for gender, population group, caregiver education and place of residence

** Adjusted for gender, caregiver education and place of residence

\section{Self-Perceived Neighborhood Social Environment}

\section{Total Sample}

Table 4 shows a relationship between population group and the neighborhood social support index $(p=0.007)$. Being Black African in comparison to White reduced the odds of reporting a positive social support environment by 51 percent $(\mathrm{OR}=0.49$ [0.31-0.77]). Being Mixed Ancestry reduced the odds by 41 percent ( $O R=0.59$ [0.36-0.96] compared to the White adolescents. There was no significant difference 
between metropolitan Johannesburg and Soweto in terms of social environment $(p=0.24)$.

Perceptions of the neighborhood security environment differed by population group, caregiver education and place of residence. Being Black African or Mixed Ancestry compared to White reduced the odds of reporting a higher neighborhood security index by 89 percent $(\mathrm{OR}=0.11$ [0.04-0.32]). Living with a caregiver who completed either no education or only primary school versus higher education reduced the odds of having a higher neighborhood security index by 74 percent ( $O R=0.26$ [0.16-0.42]). Living with a caregiver who completed only secondary school versus higher education reduced the odds by 60 percent (OR=0.40 [0.27-0.60]). Adolescents living in metropolitan Johannesburg reported having a higher neighborhood security index compared with those living in Soweto $(O R=2.48$ [ 1.77 3.47]).

Perceptions of the neighborhood social support and security environment differed by gender. Females displayed lower odds of having a positive social support environment $(\mathrm{OR}=0.83[0.69-0.99])$ and a higher neighborhood security index $(\mathrm{OR}=0.73[0.58-0.92])$ compared to males.

\section{Black African Adolescent Subsample}

There was no significant difference between Black Africans living in metropolitan Johannesburg and those living in Soweto in terms of perceptions of their neighborhood social support environment. Living with a caregiver that completed no education or only primary school versus having higher education reduced the odds of having a higher neighborhood security index by 66 percent $(O R=0.34$ [0.20$0.56]$ ). Living with a caregiver who completed only secondary school versus having higher education reduced the odds by 55 percent $(O R=0.45[0.29-0.70])$. Living in metropolitan Johannesburg increased the odds of having a higher neighborhood security index compared to living in Soweto ( $O R=2.93$ [1.96-4.36]).

Perceptions of the neighborhood security environment differed by gender. Black African females were less likely to have a higher neighborhood security environment compared to Black African males ( $\mathrm{OR}=0.72$ [0.56-0.92]). 
Table 4. Self-perceived neighborhood social environment for urban South African adolescents aged 18 years

\begin{tabular}{|c|c|c|c|c|c|c|c|c|c|c|c|c|}
\hline & \multicolumn{6}{|c|}{ Neighborhood social support index (tertiles) } & \multicolumn{6}{|c|}{ Neighborhood security index (tertiles) } \\
\hline & \multirow{2}{*}{$\mathbf{n}$} & \multirow{2}{*}{$\%$} & \multicolumn{2}{|c|}{ Unadjusted } & \multicolumn{2}{|c|}{ Adjusted } & \multirow{2}{*}{$\mathbf{n}$} & \multirow{2}{*}{$\%$} & \multicolumn{2}{|c|}{ Unadjusted } & \multicolumn{2}{|c|}{ Adjusted } \\
\hline & & & OR & $\mathrm{Cl}$ & OR & $\mathrm{Cl}$ & & & OR & $\mathbf{C l}$ & OR & $\mathbf{C l}$ \\
\hline \multicolumn{13}{|c|}{ Total sample* } \\
\hline \multicolumn{3}{|c|}{ Population group } & \multicolumn{2}{|c|}{$p=0.0037$} & \multicolumn{2}{|c|}{$p=0.007$} & & & \multicolumn{2}{|c|}{$p<0.0001$} & \multicolumn{2}{|c|}{$p=0.0003$} \\
\hline White & 114 & 6.5 & 1 & - & 1 & - & 63 & 5.3 & 1 & - & 1 & - \\
\hline Black & 1441 & 81.5 & 0.55 & $0.39-0.78$ & 0.49 & $0.31-0.77$ & 971 & 81.8 & 0.03 & $0.01-0.07$ & 0.11 & $0.04-0.32$ \\
\hline \begin{tabular}{|l|} 
Mixed \\
Ancestry \\
\end{tabular} & 213 & 12.0 & 0.59 & $0.39-0.90$ & 0.59 & $0.36-0.96$ & 153 & 12.9 & 0.04 & $0.01-0.10$ & 0.11 & $0.04-0.34$ \\
\hline \multicolumn{3}{|c|}{ Caregiver education } & \multicolumn{2}{|c|}{$p=0.22$} & \multicolumn{2}{|c|}{$p=0.34$} & & & \multicolumn{2}{|c|}{$p<0.0001$} & \multicolumn{2}{|c|}{$p<0.0001$} \\
\hline $\begin{array}{l}\text { Higher } \\
\text { education }\end{array}$ & 210 & 13.1 & 1 & - & 1 & - & 131 & 12.1 & 1 & - & 1 & - \\
\hline $\begin{array}{l}\text { Secondary } \\
\text { school }\end{array}$ & 1152 & 71.8 & 0.82 & $0.62-1.08$ & 0.92 & $0.69-1.23$ & 776 & 71.9 & 0.27 & $0.19-0.39$ & 0.40 & $0.27-0.60$ \\
\hline $\begin{array}{l}\leq \text { Primary } \\
\text { school }\end{array}$ & 242 & 15.1 & 0.96 & $0.68-1.35$ & 1.10 & $0.77-1.59$ & 173 & 16.0 & 0.17 & $0.11-0.26$ & 0.26 & $0.16-0.42$ \\
\hline \multicolumn{3}{|c|}{ Place of residence } & \multicolumn{2}{|c|}{$p=0.48$} & \multicolumn{2}{|c|}{$p=0.243$} & & & \multicolumn{2}{|c|}{$p<0.0001$} & \multicolumn{2}{|c|}{$p<0.0001$} \\
\hline Soweto & 1379 & 78.2 & 1 & - & 1 & - & 943 & 79.6 & 1 & - & 1 & - \\
\hline $\begin{array}{l}\text { Johannes- } \\
\text { burg }\end{array}$ & 384 & 21.8 & 1.08 & $0.88-1.33$ & 0.85 & $0.66-1.11$ & 242 & 20.4 & 5.25 & $3.33-8.28$ & 2.48 & $1.77-3.47$ \\
\hline \multicolumn{13}{|c|}{ Sample of black adolescents** } \\
\hline \multicolumn{3}{|c|}{ Caregiver education } & \multicolumn{2}{|c|}{$p=0.29$} & \multicolumn{2}{|c|}{$p=0.32$} & & & \multicolumn{2}{|c|}{$p=0.0001$} & $p=0$ & 0.0001 \\
\hline $\begin{array}{l}\text { Higher } \\
\text { education }\end{array}$ & 132 & 10.0 & 1 & - & 1 & - & 82 & 9.2 & 1 & - & 1 & - \\
\hline $\begin{array}{l}\text { Secondary } \\
\text { school }\end{array}$ & 966 & 73.5 & 1.06 & $0.76-1.49$ & 1.01 & $0.72-1.43$ & 656 & 73.8 & 0.42 & $0.27-0.65$ & 0.45 & $0.29-0.70$ \\
\hline $\begin{array}{l}\text { S Primary } \\
\text { school }\end{array}$ & 217 & 16.5 & 1.30 & $0.87-1.95$ & 1.25 & $0.83-1.87$ & 151 & 17.0 & 0.32 & $0.19-0.54$ & 0.34 & $0.20-0.56$ \\
\hline Place of $\mathrm{re}$ & idence & & & 0.155 & & $=0.227$ & & & $p<0$ & 0.0001 & $\mathrm{p}<0$ & 0.0001 \\
\hline Soweto & 1244 & 86.7 & 1 & - & 1 & - & 847 & 87.6 & 1 & - & 1 & - \\
\hline $\begin{array}{l}\text { Johannes- } \\
\text { burg }\end{array}$ & 191 & 13.3 & 0.81 & $0.61-1.08$ & 0.83 & $0.61-1.12$ & 120 & 12.4 & 2.86 & $1.97-4.13$ & 2.93 & $1.96-4.36$ \\
\hline
\end{tabular}

*Adjusted for gender, population group, caregiver education and place of residence

** Adjusted for gender, caregiver education and place of residence

\section{Self-Perceived Neighborhood School Environment}

\section{Total Sample}

Perceptions of the neighborhood school environment differed by population group and caregiver education (Table 5). Adjusted results show that being Black African reduced the odds of having a higher neighborhood school economic environment (e.g., high availability of facilities such as library, swimming pool, computer rooms, science labs) by 88 percent $(O R=0.12[0.05-0.28])$ and being Mixed Ancestry reduced the odds by 92 percent $(O R=0.08[0.03-0.21])$ compared to Whites. Living 
with a caregiver who completed no education or only primary school versus having higher education reduced the odds by 74 percent $(O R=0.26$ [0.16-0.42]. There was no significant difference between adolescents living in metropolitan J ohannesburg and the ones living in Soweto regarding their school environment perceptions $(p=0.06)$.

Perceptions of the school problem environment differed by population group, caregiver education and place of residence. Being Black African and Mixed Ancestry reduced the odds of reporting fewer problems at school by 46 percent and 58 percent, respectively, in comparison to White adolescents. Living with a caregiver who completed no education or only primary school education reduced the odds by 54 percent $(\mathrm{OR}=0.46[0.29-0.75])$. The odds of reporting fewer problems at school were greater when living in metropolitan Johannesburg (increase by 53 percent $(\mathrm{OR}=1.53$ [1.06-2.19]) in comparison to adolescents living in Soweto.

Perceptions of the school problem environment also differed by gender, with females displaying higher odds of reporting fewer problems at school in comparison to males (OR=1.55 [1.22-1.97]).

\section{Black African Adolescent Subsample}

In Black Africans, lower caregiver education was associated with perceptions of a lower school economic environment. Living with a caregiver who completed no education or only primary school versus having higher education reduced the odds of having a higher economic school environment by 81 percent $(O R=0.19$ [0.10$0.37])$.

There were no significant economic differences in school environments between metropolitan J ohannesburg and Soweto after adjusting for caregiver education.

The neighborhood school problem index was associated with caregiver's education and place of residence. Lower caregiver education was associated with perceptions of more problems at school. Living with a caregiver who completed no education or only primary school reduced the odds of reporting fewer problems at school by 55 percent $(\mathrm{OR}=0.45[0.27-0.76])$. The odds of reporting fewer neighborhood school problems were greater when living in metropolitan Johannesburg (increase by 52 percent $(\mathrm{OR}=1.52$ [1.03-2.23]) compared to living in Soweto and for Black African females compared to Black African males (OR=1.53 [1.19-1.98]. 
Table 5. Self-perceived neighborhood school environment for urban South African adolescents aged 18 years

\begin{tabular}{|c|c|c|c|c|c|c|c|c|c|c|c|c|}
\hline & \multicolumn{6}{|c|}{$\begin{array}{c}\text { Neighborhood school economic index } \\
\text { (tertiles) }\end{array}$} & \multicolumn{6}{|c|}{$\begin{array}{c}\text { Neighborhood school problem index } \\
\text { (tertiles) }\end{array}$} \\
\hline & \multirow{2}{*}{$\mathbf{n}$} & \multirow{2}{*}{$\%$} & \multicolumn{2}{|c|}{ Unadjusted } & \multicolumn{2}{|c|}{ Adjusted } & \multirow{2}{*}{$\mathbf{n}$} & \multirow{2}{*}{$\%$} & \multicolumn{2}{|c|}{ Unadjusted } & \multicolumn{2}{|c|}{ Adjusted } \\
\hline & & & OR & $\mathrm{Cl}$ & OR & $\mathrm{Cl}$ & & & OR & $\mathrm{Cl}$ & OR & $\mathrm{Cl}$ \\
\hline \multicolumn{13}{|c|}{ Total sample* } \\
\hline \multicolumn{3}{|c|}{ Population group } & \multicolumn{2}{|c|}{$p<0.0001$} & \multicolumn{2}{|c|}{$p<0.0001$} & & & \multicolumn{2}{|c|}{$p<0.0001$} & \multicolumn{2}{|c|}{$p=0.042$} \\
\hline White & 80 & 7.7 & 1 & - & 1 & - & 84 & 8.1 & 1 & - & 1 & - \\
\hline Black & 891 & 85.8 & 0.16 & $0.09-0.31$ & 0.12 & $0.05-0.28$ & 884 & 85.3 & 0.13 & $0.06-0.28$ & 0.54 & $0.31-0.96$ \\
\hline \begin{tabular}{|l|} 
Mixed \\
Ancestry \\
\end{tabular} & 67 & 6.5 & 0.16 & $0.09-0.30$ & 0.08 & $0.03-0.21$ & 68 & 6.6 & 0.09 & $0.02-0.32$ & 0.42 & $0.21-0.83$ \\
\hline \multicolumn{3}{|c|}{ Caregiver education } & \multicolumn{2}{|c|}{$p<0.0001$} & \multicolumn{2}{|c|}{$p<0.0001$} & & & \multicolumn{2}{|c|}{$p<0.0001$} & \multicolumn{2}{|c|}{$p=0.0077$} \\
\hline $\begin{array}{l}\text { Higher } \\
\text { education }\end{array}$ & 150 & 15.8 & 1 & - & 1 & - & 142 & 15.1 & 1 & - & 1 & - \\
\hline \begin{tabular}{|l} 
Secondary \\
school
\end{tabular} & 674 & 71.2 & 0.26 & $0.17-0.38$ & 0.33 & $0.22-0.49$ & 672 & 71.3 & 0.46 & $0.33-0.64$ & 0.66 & $0.45-0.96$ \\
\hline $\begin{array}{l}\leq \text { Primary } \\
\text { school }\end{array}$ & 123 & 13.0 & 0.22 & $0.14-0.33$ & 0.26 & $0.16-0.42$ & 129 & 13.7 & 0.32 & $0.20-0.49$ & 0.46 & $0.29-0.75$ \\
\hline \multicolumn{3}{|c|}{ Place of residence } & \multicolumn{2}{|c|}{$p<0.0001$} & \multicolumn{2}{|c|}{$p=0.06$} & & & \multicolumn{2}{|c|}{$p<0.0001$} & \multicolumn{2}{|c|}{$p=0.021$} \\
\hline Soweto & 811 & 78.4 & 1 & - & 1 & - & 805 & 78.0 & 1 & - & 1 & - \\
\hline $\begin{array}{l}\text { Johannes- } \\
\text { burg }\end{array}$ & 223 & 21.6 & 5.60 & $2.90-10.80$ & 1.42 & $0.98-2.06$ & 227 & 22.0 & 2.36 & $1.79-3.10$ & 1.53 & $1.06-2.19$ \\
\hline \multicolumn{13}{|c|}{ Sample of black adolescents** } \\
\hline \multicolumn{3}{|c|}{ Caregiver education } & \multicolumn{2}{|c|}{$p<0.0001$} & \multicolumn{4}{|c|}{$p<0.0001$} & \multicolumn{2}{|c|}{$p=0.0040$} & & $=0.011$ \\
\hline \begin{tabular}{|l|} 
Higher \\
education
\end{tabular} & 92 & 11.3 & 1 & - & 1 & - & 84 & 10.4 & 1 & - & 1 & - \\
\hline \begin{tabular}{|l} 
Secondary \\
school
\end{tabular} & 610 & 74.7 & 0.31 & $0.21-0.48$ & 0.25 & $0.14-0.44$ & 605 & 74.8 & 0.60 & $0.40-0.91$ & 0.66 & $0.43-1.02$ \\
\hline $\begin{array}{l}\leq \text { Primary } \\
\text { school }\end{array}$ & 115 & 14.0 & 0.25 & $0.16-0.41$ & 0.19 & $0.10-0.37$ & 120 & 14.8 & 0.41 & $0.25-0.70$ & 0.45 & $0.27-0.76$ \\
\hline Place of $r$ & esider & & & $=0.039$ & & $=0.137$ & & & & $=0.005$ & & $=0.035$ \\
\hline Soweto & 767 & 86.5 & 1 & - & 1 & - & 762 & 86.6 & 1 & - & 1 & - \\
\hline $\begin{array}{l}\text { Johannes- } \\
\text { burg }\end{array}$ & 120 & 13.5 & 1.80 & $1.03-3.15$ & 1.60 & $0.86-2.99$ & 118 & 13.4 & 1.66 & $1.16-2.37$ & 1.52 & $1.03-2.23$ \\
\hline
\end{tabular}

*Adjusted for gender, population group, caregiver education and place of residence

** Adjusted for gender, caregiver education and place of residence

\section{Discussion}

The purpose of this research was to determine adolescents' perceptions of their socio-economic and school neighborhood environments and to collate experiences of living in a transitioning urban environment. This dataset provided a unique opportunity to examine deprivation at the neighborhood level in adolescents who were born in 1990-as Nelson Mandela was being released from prison and 
Apartheid was ending. While there is evidence of a national collective identity among adolescents living in Johannesburg (Norris et al. 2008), there remain extreme differences in the economic well-being of South Africans with large differences across population groups' socio-economic environments. The study shows that the adolescents' responses to questions on neighborhood socioeconomic and school environments are statistically significantly different according to population group, gender, place of residence and level of caregiver education.

The neighborhood socio-economic findings of this study are strongly suggestive of underlying inequalities among adolescents living in this area, with the Black African and Mixed Ancestry groups still being the most disadvantaged. South Africa is known as being the most unequal society in the world (World Bank 2014). Black African and Mixed Ancestry adolescents reported a lower overall neighborhood economic environment (i.e., they were less likely to have a higher neighborhood economic index, high availability of services, and low neighborhood problems) as well as a less favorable social support environment in comparison to Whites. When examining socio-economic differences among Black African adolescents only, differences were seen in terms of perceptions of economic status between those living in metropolitan Johannesburg versus those living in Soweto. Black African adolescents living in metropolitan Johannesburg reported more favorable environments. These perceptions may be associated with the level of development of the place of residence, with Soweto being less economically developed and displaying high rates of poverty compared to metropolitan Johannesburg (City of Johannesburg 2014). However, no differences were seen between the two places in terms of social support environment, neighborhood availability of services or level of neighborhood problems.

These results corroborate with the literature on socio-economic inequalities in South Africa, which demonstrates that since 1994 inequality has worsened (Mooney and Gilson 2009) and disparities within specific population groups have widened (May 1998; Bhorat and Kanbur 2006; Leibbrandt, Wegner and Finn 2011). However, the present study highlights new results in relation to the social environment. Namely, while Black African and Mixed Ancestry adolescents reported a less favorable economic environment, they also experienced a more favorable social environment in terms of community spirit, time spent with friends and liveliness compared to their White peers, although the overall social support environment was lower in Black and Mixed Ancestry adolescents. This might come from the fact that the social support index incorporated dimensions of both trust towards neighbors and community atmosphere (community spirit, liveliness, happiness, etc.), which generated divergent responses. For instance, 28.3 percent of Black African and 24.7 percent of Mixed Ancestry adolescents reported that they trust nobody in their neighborhood other than their family, compared to 14.3 percent of White adolescents. 65.5 percent of Black Africans stated that they could ask their neighbors to look after their house compared to 80.2 percent in the White group. In terms of community atmosphere, community spirit was reported to be strong by 38.4 percent and 35.3 percent of Black African and Mixed Ancestry adolescents, respectively, as opposed to 9.5 percent of White adolescents. More than 40 percent of the Black African and Mixed Ancestry sample reported their neighborhood to be 
lively as opposed to 27.0 percent of the White group. Finally, Black African and Mixed Ancestry adolescents spent significantly more time with their friends than did White adolescents.

This study also demonstrates perceived inequalities in the school environment. Black African and Mixed Ancestry adolescents reported studying in a less favorable school environment (less likely to have a higher school economic index and low school problems) in comparison to Whites. Black African adolescents living in Soweto reported experiencing more problems at school than those living in metropolitan Johannesburg. The school economic environment, however, was not different between Black Africans living in metropolitan Johannesburg and Soweto after adjusting for caregiver education. This demonstrates that there is no place effect in neighborhood school economic environment but rather that caregiver education levels are different between the two areas. This fact suggests that adolescents with less educated parents who are living in Soweto are having the likelihood of poor educational outcomes being perpetuated across generations because of the quality of the school environments that they are experiencing.

The school findings discussed above have strong policy implications as the differences seen are not exclusive to population group. Rather, within the Black African group, living in Soweto is more likely to result in educational disadvantage compared to living in metropolitan Johannesburg. The school environment is an important part of an adolescent's neighborhood. The current study is in line with previous research showing that the school setting in South Africa can be hostile and unfavorable for education, with a lack of trained teachers, facilities and educational resources (Van der Berg 2002; Barbarin 2003; OECD 2013). However, it also shows that there is varying quality in school environments. Although the abolition of Apartheid led to a decrease in political violence, this was replaced to some extent with community and interpersonal violence (Jenkins 1997; Seekings 2000; Barbarin and Richter 2001; Seedat et al. 2009). Children in post-Apartheid South Africa were exposed to extreme violence and psychosocial distress (Lockhat and Van Niekerk 2000; Barbarin, Richter and de Wet 2001). A core element of school integration is feeling safe while in the educational environment (Brookmeyer, Fanti and Henrich 2006; McNeely, Nonnemaker and Blum 2002). In the present study, around 20 percent of adolescents feel unsafe or moderately safe at school. Furthermore, the school climate is a key determinant of school absenteeism and is inversely related to class and school size (Brookmeyer, Fanti and Henrich 2006). In this study, around 65 percent and 40 percent of adolescents reported absenteeism and overcrowding, respectively, as issues in their schools.

Demombynes and Özler (2005) showed that crime and socio-economic inequality are interconnected, and that within-group inequality is a significant predictor of violence (Seedat et al. 2009). The neighborhood problems (shebeens, alcohol abuse, illegal dumping, lack of park and sports facilities, lack of police officers patrolling the neighborhood) and school problems (lack of educational resources) reported in the current study corroborate with a previous qualitative participatory study on young adolescents' daily living conditions (Kruger and Chawla 2002). Kruger and Chawla's (2002) study of young adolescents (10-14 years old) residing 
in low SES neighborhoods in the Greater Johannesburg region highlighted a multitude of problems in their daily lives. Some problems were ubiquitous (insufficient and unsafe place for play, presence of shebeens, alcohol abuse, harassment, poor waste management) and others were neighborhood-specific (drug abuse, unemployment, rape, lack of police station, lack of educational resources, etc.). All these problems resulted in a high level of fear towards the outside environment and adolescents felt restrained in the way they interact with their neighborhoods (Kruger and Chawla 2002). The current study shows that adolescents reporting higher crime are the ones more socio-economically disadvantaged. Furthermore, 81.3 percent of adolescents reported unemployment as an issue and this was mainly found in the Black African and Mixed Ancestry groups. The high level of crime and unemployment in this sample corroborate the findings of previous studies (Seekings 2000; Seedat et al. 2009), who reported that crime and unemployment are the issues predominantly facing South Africa. Around 30 percent of South Africa's population is unemployed (Statistics South Africa 2011) and youth unemployment remains a challenge. The present study adds to the literature by showing that Black Africans living in Soweto are the most vulnerable and experience the highest levels of crime out of all adolescents in the study.

A previous study in the Bt20 cohort revealed that, although housing, water and sanitation conditions have improved, socio-economic inequalities still exist at the household level (Richter et al. 2009). The present study strengthens the evidence for socio-economic inequalities within and between the different population groups at the neighborhood level based on adolescents' perceptions. It also brings unique information on Black Africans who have moved from Soweto to metropolitan Johannesburg compared to the ones still residing in Soweto and suggests that they have not gained in terms of social provision, availability of services, experiences of neighborhood problems or school provision. However they do appear to have reduced their economic disadvantage and experience less problems at school.

While gender differences in perceptions of the neighborhood socio-economic environment were not the primary aim of this study, some differences were apparent in the responses of males and females. Gender differences in the perception of neighborhood and school problem environments could be explained by the fact that males engage more with the outside environment and are therefore more aware of the existing problems. Females might spend less time outside due to their important social role within the household but also because of parents' fear towards the environment in which these girls reside and the potential risks that they may face. Previous qualitative studies highlighted that females are more cautious and experience a limited range of mobility compared to males (Bannerjee and Driskell 2002; Adams and Savahl 2013).

Another key element is that population group differences remain despite controlling for caregiver education, gender and place of residence for all the neighborhood socio-economic and school environment measures, which reveal that the population group differences are not explained by differences in the education level of the primary caregiver, place of residence or gender. 
Finally, although White participants reported more positive neighborhoods relative to Black African and Mixed Ancestry adolescents, it is important to highlight that they did not report perfect neighborhoods and improvements could be achieved.

Many qualitative studies have focused on children and adolescents' perceptions of their environment (Chawla 2001a; Kruger and Chawla 2002; Chawla and Driskell 2006; Adams and Savahl 2013), however the current study is the first to assess quantitatively the neighborhood socio-economic and school environments in South Africa. Furthermore, this paper provides a thorough analysis of both the economic and social environment across different population groups. Although the neighborhood SES tool was developed to describe the environment in which the adolescents reside, it can have value in decision making regarding the allocation of resources to specific areas of need and for the definition of appropriate policies (Sheppard et al. 2010). One limitation of this study, however, is the relatively low number of Indian adolescents, which precluded the inclusion of this group in the univariate and multivariate analyses. Further studies using oversampling techniques are urgently required to capture Indians' perceptions of their neighborhood SES environment. Further work could also explore more in depth the association between gender roles and perceptions of the neighborhood socio-economic environment.

Reducing neighborhood poverty, inequality and violence remains a challenge and a priority in the area of Johannesburg and Soweto. Improvements in the school environment may be an important means of addressing socio-economic disparities through promoting better education, increasing job opportunities and developing economic empowerment for the disadvantaged groups (Van der Berg 2002). In order to reduce violence and crime and improve social aspects of neighborhoods, a sense of community spirit should be nurtured (Barbarin 2003). Adolescents are key stakeholders in the community and as such, they contribute to creating a favorable environment that ensures adequate development for themselves and for future generations (Chawla 2001a; 2001b; 2002; Chawla and Driskell 2006). In this study, the proportion of adolescents reporting a strong community spirit was relatively low (below 40 percent), suggesting that improvement is needed. Community atmosphere (trust, happiness, liveliness, community spirit) could be improved through grassroots programs, community engagement and empowerment. Key informants in the community (community leaders, parents, government officials, etc.) could nurture a sense of responsibility among community members and promote collective action to solve common neighborhood problems (Chawla 2001a; 2001b; 2002; Chawla and Driskell 2006).

A willingness from the government to incorporate the views of these adolescents when implementing policy is essential (Chawla and Driskell 2006). The key differences that have been highlighted by adolescents are economic factors both in the neighborhood and school environments. Thus policy makers need to design initiatives to reduce the economic differences between the different population groups and between Johannesburg and Soweto. The fact that a gradient exists in the scale of problems in the neighborhoods and schools opens up the possibility for 
some neighborhoods to act as role models for others and for policies to draw on pre-existing frameworks.

\section{Endnote}

i. Ethical approval was granted by the ethics committee of the University of the Witwatersrand (Protocol number M980810), South Africa, for primary data collection. The primary caregiver gave written informed consent for their child to participate in the assessment and the adolescent provided written assent or consent if aged 18 years or more. Ethical approval was also granted by the ethics committee of Loughborough University, UK (Generic protocol G08P9) for clearance for secondary data analyses of the cohort data.

Rebecca Pradeilles is a Ph.D. student at Loughborough University in the Centre for Global Health and Human Development. She is interested in socio-economic inequalities relating to poor health, in particular obesity-related non-communicable diseases, predominantly in African populations. Her research has focused upon the relationship between socio-economic factors at the neighborhood and household levels with nutrition and obesity, in adolescents and adults in South Africa, Morocco and Tunisia.

Emily Rousham, Ph.D. in child growth and nutrition is a lecturer in Human Biology at Loughborough University in the Centre for Global Health and Human Development. Her academic research focuses predominantly on maternal, child and adolescent health with a particular interest in the relationship between nutrition, growth and infection in children in low- and middle-income countries.

Professor Shane Norris is the Director of the MRC/Wits Developmental Pathways for Health Research Unit in the Department of Pediatrics at the University of the Witwatersrand, Johannesburg and he has an honorary appointment at the University of Cambridge. He is Co-PI of the Birth to Twenty Plus Cohort and has over 15 years of research experience in child health with a particular research interest in growth, obesity, and metabolic disease risk.

Paula Griffiths, Ph.D. in social statistics, is a reader in Biosocial Science at Loughborough University in the Centre for Global Health and Human Development. Her academic research focuses predominantly on inequalities in maternal and early life risk factors for chronic disease outcomes, particularly in South Africa, Kenya, India, and the UK. Her current work is especially focusing on the role of changing socio-economic circumstances over the early lifecourse and how these influence health outcomes in children and adolescents. 


\section{References}

Adams, Sabirah and Shazly Savahl (2013). “Children's Perceptions of the Natural Environment: A South African Perspective." Children's Geographies DOI: http: // dx.doi.org/10.1080/14733285.2013.829659

Bannerjee, Kanchan and David Driskell (2002). "Tales from Truth Town." In Chawla, Louise, ed. Growing Up in an Urbanising World. Paris: Earthscan/UNESCO, 135- 160.

Barbarin, Oscar A. (2003). "Social Risks and Child Development in South Africa: A Nation's Program to Protect the Human Rights of Children." American J ournal of Orthopsychiatry 73(3): 248-259.

Barbarin, Oscar A. and Linda M. Richter, eds. (2001). Mandela's Children: Growing up in a Post-Apartheid South Africa. Psychology Press.

Barbarin, Oscar A., Linda Richter and Thea de Wet (2001). "Exposure to Violence, Coping Resources, and Psychological Adjustment of South African Children." American J ournal of Orthopsychiatry 71(1): 16-25.

Beall, Jo, Owen Crankshaw and Susan Parnell (2000). "Local Government, Poverty Reduction and I nequality in J ohannesburg." Environment and Urbanization 12(1): 107-122.

Beall, J o, Owen Crankshaw and Susan Parnell (2003). "Uniting a Divided City: Governance and Social Exclusion in Johannesburg." Review of African Political Economy 30(95): 171-176.

Bhorat, Haroon and Ravi Kanbur (2006). "Poverty and Well-Being in PostApartheid South Africa." In Haroon, Bhorat and Ravi Kanbur, eds. Poverty and Policy in Post-Apartheid South Africa. Pretoria: HSRC Press, 1-18.

Brookmeyer, Kathryn A., Kostas A. Fanti and Christopher C. Henrich (2006). "Schools, Parents, and Youth Violence: A Multilevel, Ecological Analysis." J ournal of Clinical Child and Adolescent Psychology 35(4): 504-514.

Brooks-Gunn, Jeanne, Greg J. Duncan, Pamela K. Klebanov and Naomi Sealand (1993). "Do Neighborhoods I nfluence Child and Adolescent Development?" American J ournal of Sociology 99(2): 353- 395.

Brooks-Gunn, J eanne and Greg J. Duncan (1997). "The Effects of Poverty on Children." The Future of Children 7(2): 55-71.

Cameron, Noël (2003). "Physical Growth in a Transitional Economy: The Aftermath of South African Apartheid." Economics \& Human Biology 1(1): 29-42. 
Chawla, Louise, ed. (2001a). Growing Up in an Urbanizing World. Paris: Earthscan/UNESCO.

---- (2001b). "Putting Young Old Ideas into Action: The relevance of Growing up in Cities to Local Agenda 21." Local Environment: The International J ournal of J ustice and Sustainability 6(1): 13-25.

---- (2002). “Insight, Creativity and Thoughts on the Environment: Integrating Children and Youth into Human Settlement Development." Environment and Urbanization 14(2): 11-22.

Chawla, Louise and David Driskell (2006). "The Growing Up in Cities Project." Journal of Community Practice 14(1-2): 183-200.

Chopra, Mickey, J oy E. Lawn, David Sanders, Peter Barron, Salim S. Abdool Karim, Debbie Bradshaw, Rachel Jewkes, Quarraisha Abdool Karim, Alan J. Flisher and Bongani M. Mayosi (2009). "Achieving the Health Millennium Development Goals for South Africa: Challenges and Priorities." The Lancet 374(9694): 1023-1031.

Christopher, A.J ., ed. (1994). The Atlas of Apartheid. London: Routledge.

City of J ohannesburg (2005). "Human Development Strategy: Joburg's Commitment to the Poor." Office of the City Manager: J ohannesburg.

---- (2014). “Integrated Annual Report 2012/2013." Available from:

http: // www.joburg.org.za/images/October/annexure\%20b.pdf

de Wet, Thea, Leila Patel, Marcel Korth and Chris Forrester (2008). "J ohannesburg Poverty and Livelihoods Study." Centre for Social Development in Africa, Johannesburg. Available from:

http://www.ncr.org.za/pdfs/Research_Reports/Livelihoods\%20study. pdf.

Demombynes, Gabriel and Berk Özler (2005). "Crime and Local I nequality in South Africa." Journal of Development Economics 76(2): 265-292.

Griffiths, Paula L., Zoë A. Sheppard, William J ohnson, Noël Cameron, J ohn M. Pettifor and Shane A. Norris (2012). "Associations between Household and Neighbourhood Socioeconomic Status and Systolic Blood Pressure among Urban South African Adolescents." J ournal of Biosocial Science 44(4): 433-458.

Griffiths, Paula L., William Johnson, Noël Cameron, J ohn M. Pettifor and Shane A. Norris (2013). "In Urban South Africa 16 Year Old Adolescents Experience Greater Health Equality Than Children." Economics \& Human Biology 11(4): 502-514.

Hoogeveen, J ohannes G. and Berk Özler (2004). "Not Separate, Not Equal: Poverty and Inequality in Post-Apartheid South Africa." William Davidson Institute 
Working paper No.739, Ann Arbor: University of Michigan.

J enkins, J ohn W. (1997). "Urbanisation and Security in South Africa: The Continuation of History." African Security Review 6(6): 54-62.

Kruger, J ill S. and Louise Chawla (2002). "We Know Something Someone Doesn't Know: Children Speak out on Local Conditions in J ohannesburg." Environment and Urbanization 14(2): 85-96.

Leibbrandt, Murray, Eva Wegner and Arden Finn (2011). "The Policies for Reducing Income I nequality and Poverty in South Africa." A Southern Africa Labour and Development Research Unit Working Paper Number 64. Cape Town: SALDRU, University of Cape Town. Available from:

http://saldru.com.uct.ac.za/bitstream/handle/11090/79/2011_64. pdf? sequence=1

Lester, Alan, Etienne Nel and Tony Binns, eds. (2000). South Africa, Past, Present and Future. England: Pearson Education Limited.

Lockhat, Rafiq and Ashley Van Niekerk (2000). "South African Children: A History of Adversity, Violence and Trauma." Ethnicity and Health 5(3-4): 291-302.

Mandela, Nelson R., ed. (1994). Long Walk to Freedom. London: Abacus.

May, J ulian, ed. (2000). Poverty and Inequality in South Africa: Meeting the Challenge. Africa: David Philip Publishers.

May, J ulian and J uby Govender (1998). "Poverty and Inequality in South Africa." Indicator South Africa 15: 53-58. Available from:

http: //www.info.gov.za/otherdocs/1998/poverty/presentation. pdf

McNeely, Clea A., James M. Nonnemaker and Robert W. Blum (2002). "Promoting School Connectedness: Evidence from the National Longitudinal Study of Adolescent Health." J ournal of School Health 72(4): 138-146.

Meth, Charles and Rosa Dias (2004). "Increases in Poverty in South Africa, 1999-2002." Development Southern Africa 21(1): 59-85.

Mooney, Gavin and Lucy Gilson (2009). "The Economic Situation in South Africa and Health Inequities." The Lancet 374(9693): 858-859.

Norris, Shane A., Robert W. Roeser, Linda M. Richter, Nina Lewin, Carren Ginsburg, Stella A. Fleetwood, Elizabeth Taole and Kees van der Wolf (2008). "South African-ness among Adolescents: The Emergence of a Collective Identity within the Birth to Twenty Cohort Study." The Journal of Early Adolescence 28(1): 51-69.

Organisation for Economic Co-operation and Development (OECD) (2013). Economic Surveys SOUTH AFRICA. Available from: 
http: // www.oecd.org/ eco/surveys/South\% 20Africa\% 202013\% 200verview\% 20FINA L.pdf

Posel, Dorrit and Michael Rogan (2013). “Measured as Poor versus Feeling Poor: Comparing Objective and Subjective Poverty Rates in South Africa." Paper prepared for the ESSA Conference. Available from:

http: // www.essa2013.org.za/fullpaper/essa2013_2502.pdf.

Richter, Linda M., Shane A. Norris, J ohn M. Pettifor, Derek Yach and Noël Cameron (2007). "Cohort Profile: Mandela's Children: The 1990 Birth to Twenty Study in South Africa." International Journal of Epidemiology 36(3): 504-511.

Richter, Linda M., Saadhna Panday, Tanya M. Swart and Shane A. Norris (2009). "Adolescents in the City: Material and Social Living Conditions in Johannesburg-Soweto, South Africa." Urban Forum 20: 319-334.

Roberts, Martin, ed. (2001). South Africa 1948-2000: The Rise and Fall of Apartheid, $3^{\text {rd }}$ edition. England: Pearson Education Limited.

Seedat, Mohamed, Ashley Van Niekerk, Rachel Jewkes, Shahnaaz Suffla and Kopano Ratele (2009). "Violence and Injuries in South Africa: Prioritising an Agenda for Prevention." The Lancet 374: 1011-1022.

Seekings, Jeremy (2000). "I ntroduction: Urban Studies in South Africa after Apartheid." International Journal of Urban and Regional Research 24(4): 832-840.

Sheppard, Zoë, Shane A. Norris, J ohn M. Pettifor, Noël Cameron and Paula L. Griffiths (2009). "Approaches for Assessing the Role of Household Socioeconomic Status on Child Anthropometric Measures in Urban South Africa." American Journal of Human Biology 21: 48-54.

Sheppard, Zoë, Shane A. Norris, J ohn M. Pettifor, Noël Cameron and Paula L. Griffiths (2010). “How Can We Learn about Community Socio-Economic Status and Poverty in a Developing Country Urban Environment? An Example from Johannesburg-Soweto." African Population Studies 24(1-2): 53-69.

Statistics South Africa (2011). Available from: http: // www.statssa.gov.za/publications/ P03014/P030142011.pdf.

United Nations Development Programme (UNDP) (2013). “Millennium Development Goals: Country Report 2013. The South Africa I Know, the Home I Understand." Available from:

http: // www.za.undp.org/content/dam/south_africa/docs/Reports/The_Report/MDG _October-2013.pdf

Van der Berg, Servaas (2002). "Education, Poverty and I nequality in South Africa." Paper presented at the Conference of the Centre for the Study of African Economies, on Economic Growth and Poverty in Africa. Oxford, March. Available 
from: http: //www.csae.ox.ac.uk/conferences/2002-UPaGiSSA/papers/vanderBergcsae2002.pdf

World Bank (2014). "GINI Index." Available from:

http: // data. worldbank.org/indicator/SI .POV.GI NI . 